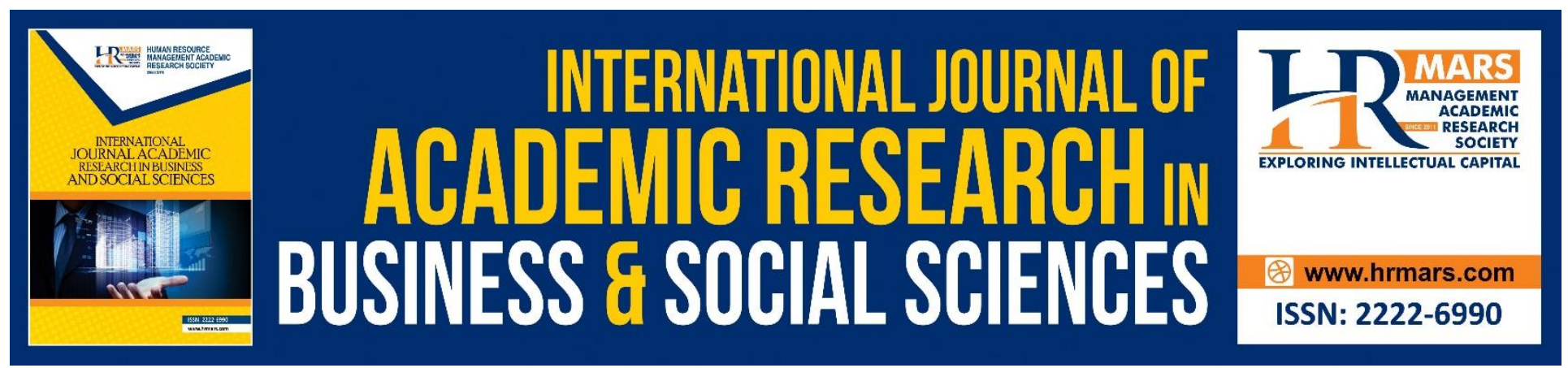

\title{
The Source of Sabab Nuzul Ayah (The Contexts and Occasions of The Revelation of the Qur'an) in Tafsir Nur al- Ihsarn: An Intertextuality Study
}

Mohd Sholeh Sheh Yusuff, Yusuf Haji-Othman, Mat Rani Abdul Manaf

To Link this Article: http://dx.doi.org/10.6007/IJARBSS/v9-i2/5510 DOI: $10.6007 /$ IJARBSS/v9-i2/5510

Received: 07 Jan 2019, Revised: 21 Feb 2019, Accepted: 25 Feb 2019

Published Online: 03 March 2019

In-Text Citation: (Yusuff, Haji-Othman, \& Manaf, 2019)

To Cite this Article: Yusuff, M. S. S., Haji-Othman, Y., \& Manaf, M. R. A. (2019). The Source of Sabab Nuzul Ayah (The Contexts and Occasions of The Revelation of the Qur'an) in Tafsir Nur al-Ihsan: An Intertextuality Study. International Journal of Academic Research in Business and Social Sciences, 9(2), 487-496.

Copyright: (C) 2019 The Author(s)

Published by Human Resource Management Academic Research Society (www.hrmars.com)

This article is published under the Creative Commons Attribution (CC BY 4.0) license. Anyone may reproduce, distribute, translate and create derivative works of this article (for both commercial and non-commercial purposes), subject to full attribution to the original publication and authors. The full terms of this license may be seen at: http://creativecommons.org/licences/by/4.0/legalcode

Vol. 9, No. 2, 2019, Pg. 487 - 496

http://hrmars.com/index.php/pages/detail/IJARBSS

JOURNAL HOMEPAGE

Full Terms \& Conditions of access and use can be found at http://hrmars.com/index.php/pages/detail/publication-ethics 


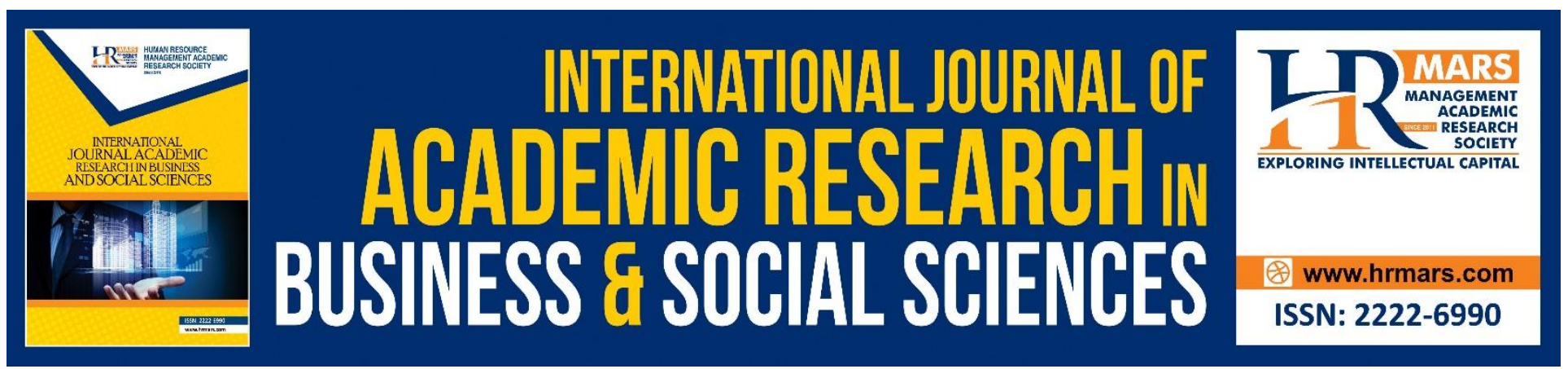

\title{
The Source of Sabab Nuzul Ayah (The Contexts and Occasions of The Revelation of the Qur'an) in Tafsir Nur al-Ihsan: An Intertextuality Study
}

\author{
Mohd Sholeh Sheh Yusuff ${ }^{1}$, Yusuf Haji-Othman², Mat Rani Abdul \\ Manaf ${ }^{3}$ \\ ${ }^{1,3}$ Kulliyyah of Usuluddin and Quranic Sciences, Sultan Abdul Halim Mua'dzam Shah International \\ Islamic University, 09300 Kuala Ketil, Kedah, Malaysia \\ ${ }^{2}$ Center for Islamic Finance Education and Research, Sultan Abdul Halim Mua'dzam Shah \\ International Islamic University, 09300 Kuala Ketil, Kedah, Malaysia
}

\begin{abstract}
Tafsir Nur al-Ihsan is the second interpretation after Tarjuman al-Mustafid written in the Malay language in the 19th century AD by Omar (1970). The main objective of this study is to identify the influence of the external source in the text of Tafsir Nur al-Ihsan about Sabab Nuzul Ayah (The Contexts and Occasions of The Revelation of The Quran). Intertextual reading method is used in the process of analyzing Tafsir Nur al-Ihsan founded by Bakhtin and descriptions, developed and analyzed by Krestiva (1980). This study employs library research and fieldwork using the subjective approach which is descriptive. The study found seven works which have influenced the essence of Sabab Nuzul Ayah (The Contexts and Occasions of The Revelation of The Quran), which are Tafsir al-Jalalyn, Tafsir al-Jamal, Tafsir al-Baydawi, Tafsir al-Khazin, Tafsir al-Qurtubi, Tafsir al-Razi, and Tafsir al-Nasafi. The finding analysis also shows that Tafsir Nur al-Ihsan is mostly influenced by Tafsir al-Jalalyn.
\end{abstract}

Keyword: Tafsir Nur al-Ihsan; Sabab Nuzul Ayah; Intertextuality Study; intertextuality principle

\section{Introduction}

The writings of Islamic works and translations into the Malay language have grown tremendously since the coming of Islam to Nusantara regions (Malaysia, Thailand, Brunei, and Indonesia), which have covered various fields and branches of knowledge such as fiqh, aqidah, tafsir, hadith, and Sufism, among others. The writings and translations by previous Islamic scholars remain as important sources of reference and are still used by contemporary scholars for academic purposes. It proves the success of previous scholars who produced writings which have not only attracted the interest of the public but also have benefited them. One of the scholars is Omar, M. S. who produced a book in the field of tafsir in Malay language entitled Tafsir Nur al-Ihsan

in 1970. 
Tafsir Nur al-Ihsan is a well-known work which was written by Omar in 1970. Writing this work was time-consuming for it took two years nine months to complete, and it was successfully completed on the $1^{\text {st }}$ of October 1927 (Omar, 1970). This work is one of the works in the fields of tafsir al-Qur'an of the earliest produced in the Malay world after Tarjuman al-Mustafid by Sheikh Abdul Rauf al-Singkeli in the 17th century (Nasyrudin, 2008).

Tafsir Nur al-Ihsan began to be printed by the first print in 1934 in Mecca by Maktabah wa Matbaah Muhammad al-Nahdi wa Awladih and second print was in the year of 1936 in Penang. The third printing of the work was in the year 1391 Hijrah equivalent to 1970 by al-Muarif Sdn. Bhd, Matba'ah bin Halabi in Fathani and Matbaah Muhammad al-Nahdi wa Awladih in Bangkok, Thailand. Meanwhile, there is also a print published by Dar al-Ihya' al-Kutub al-Arabiyyah, Egypt in the year 1349 Hijrah. Each print of Tafsir Nur al-Ihsan must first obtain the consent of the heirs of Omar and signature of the permission can be seen on each page per volume (Othman, 2012).

Tafsir Nur al-Ihsan produced by Omar (1970) came in four volumes and each volume is sorted according to the chapters (surah) of al-Quran. The first volume covers the Surah al-Fatihah to alMaidah, the second volume covers al-An'am to Surah Hud, the third volume includes Surah al-Kahf to al-Zumar, and the fourth volume covers al-Mukmin to Surah al-Nas. Tafsir Nur al-Ihsan is quite difficult to be obtained on the market and it is only sold in certain bookstores only. Most of the works circulating in the market these days are printed by the company from Bangkok measuring $26.5 \mathrm{~cm} \mathrm{x}$ $20 \mathrm{~cm}$.

This work is widely circulated particularly in the State of Kedah, Malaysia and even in Northern Perak, Malaysia, Penang, and Seberang Prai, Malaysia also in southern Thailand (Abdul Rahman, 2010). Tafsir Nur al-Ihsan is a work in the fields of tafsir al-Quran in the Malay language written using Jawi which has given many benefits to the Muslims, especially in Malaysia, while it is also a best-effort made by Omar (1970) that has been passed on to the community until today. The content of this work is complete and comprehensive accounting for the description of the contexts and occasions of the revelation of the Quran, the virtues of surah and verse, problems of Fiqh, al-Mutashabihat, alNasikh and al-Mansukh plus stories of previous generations.

Tafsir Nur al-Ihsan has been used as a reference in understanding Qur'anic verses not only by the public but also by contemporary scholars who have used it as teaching material. This invaluable piece of work has given a contribution to the knowledge of the public at large so much so that scholars are attracted to study and examine this work from various aspects such as history, language, the influence, and stature of the author.

Tafsir Nur al-Ihsan is also one of the books on tafsir al-Qur'an which is still being used as teaching material and reference today especially at Pondok institutions, mosques, and musollas. Pondok institutions such as Pondok Tuan Guru Haji Bakar at Parit Panjang, Baling, Kedah, Malaysia and Pondok Tuan Guru Haji Soleh Musa at Sik, Kedah, Malaysia have been using the book as the teaching 
material for their weekly teaching. However, there have been criticisms on the content of Tafsir Nur al-Ihsan by certain sections of the public. Some of them opined that this book has its shortcomings because, in the writing of this book, the author does not mention any citation and uses many unjustified opinions in his tafsir (Zaim, 2010), so much so that Muhammad Ismi stressed that the public should be careful when reading Tafsir Nur al-Ihsan (Taib, 2003).

The motivation of this study is to make effort to help overcome the shortcoming of this invaluable piece of work by refining sources of reference and interconnections between the original text and other tafsir texts using intertextual reading. Since Tafsir Nur al-Ihsan has been used as teaching material in the tafsir al-Qur'an and a reference by the public at large in understanding verses of alQur'an, then efforts to refine this piece of work should be made. This will answer the aforementioned problem statement. The objective of this study is to examine Tafsir Nur al-Ihsan in order to examine whether there exists the influence of other texts on the text of Tafsir Nur al-Ihsan using intertextual reading. This study focuses on Sabab Nuzul Ayah (The Contexts and Occasions of The Revelation of The Quran) on the text of Tafsir Nur al-Ihsan as an early effort towards the refinement of the text which contributes to improving the invaluable work. Since the author of Tafsir Nur al-Ihsan mentioned that he referred to works in the field of tafsir while in the process of writing (Omar, 1970), this study focuses only on tafsir works.

\section{Research Method}

This study employs library research and field study using a subjective approach to examine data descriptively and quantitatively. In order to examine whether there exists the influence of other texts on the text of Tafsir Nur al-Ihsan, this study employs the method of intertextual reading. The intertextual reading method was originally known as dialogic which was introduced by Bakhtin in the year 1926 because there was voluminous Russian art literature which was difficult to comprehend at that time. As a consequence, this theory was introduced by Bakhtin in order to facilitate readers to understand the difficult literature. This theory pictured that all literature which was written were based on dialogues between one text and another. In other words, this theory states that any text is influenced by other texts. This is supported by Harari (1979), who mentioned that "every text, being itself the intertext of another text, belong to the intertextual, which must not be confused with a text's origins".

The basis of this dialogic theory is used to understand Dostoyevsky's literature such as The Gambler, The Idiot, and The Brother's Karamazov which were considered as difficult to be understood by the public using theories of literature such as formalism which were dominant during that time (Dostoyevsky, 1975). The Russian formalism approach which was on the rise during that time did not help the public to understand the approach of Dostoyevsky's literature. Bakhtin's dialogism emphasized external aspect which influenced reading or how an author approached art literature and in turn would flow naturally into his own literature writing. However, Bakhtin did not deny the importance of internal elements such as theme, thinking, plot, characters, and other elements.

In the theory of dialogism, an author would have a dialogue with the text itself, himself and readers. This would create dialogues between text and another text and as a consequence, it would trigger 
changes, conflicts, and expansion in the literature which was being written by the author in terms of theme and problems, plot or characters and characterization. Therefore, the connection between external and internal structures in literature is important in this approach. According to Schmitz (2007), sentences used by someone in speech or writing interconnects among them and if there is no dependency among them, then any sentence or speech becomes gloomy and inexpendable. Schmitz (2007) mentioned;

"Language always works within certain situations, and utterances produce their significance within this context. The linguistic material alone is not enough to determine whether a word or a sound is enthusiastic, gloomy, ironical, threatening, or deferential; rather, this depends on a number of factors such as intonation, volume, the interlocutor, and prior utterances in the dialogue"(Schmitz 2007, 66-67).

This theory was later discussed by Kristeva (1980) who did not name this theory as dialogic, instead, she termed it as intertextuality. Hawthorn (2000) mentioned that every text written is influenced by other texts and this influence is discussed in intertextual theory. Therefore, readers should not be confused with the original text which is the hipogram of a given text. Jeremy Hawthorn (2000) stated that "Kristeva defines the text as a permutation of texts, an intertext in the space of a given text...".

The development of this theory not only have taken place in Europe but also in the whole worldwide. In Southeast Asia, it has been discussed as one of modern literary theory in which one scholar in the field of literature named Partini Sardjono has developed this theory. He has not only stood on the principles of Kristeva but has also introduced another principle termed as an excerpt. This principle applies when a text incarnated in another text in an abstract form. Subsequently, there was the birth of new names in Indonesia such as Teeuw and Omar. Meanwhile, in Malaysia and Singapore, it became known after Napiah (1989) discussed in several books, particularly in his Ph.D. thesis entitled "Tuah Jebat in Malay Drama: A Study of intertextuality". In this thesis, he not only discussed this theory at length but also applied it to the book entitled Hikayat Hang Tuah (Wan Nasyrudin, 2008).

Based on Kristeva (1980) and Sardjono (1986), there are 10 intertextual principles which have often appeared in literature and manifestation reflected in a person's style of writing, namely:

i. Transformation.

Transformation refers to either a formal or abstract transfer, transformation or conversion of a text to another text (Kristeva 1980, 80).

ii. Modification principle.

Modification principle occurs when the author makes adjustments, changes or amendments on certain text in a given text. This principle occurs due to the desire of the author to retrieve or replicate a text into another text and adjusts it according to the wants of society, culture, politics and readers' minds (Kristeva 1980, 90).

iii. Expansion.

Expansion occurs when an author expands or develops a text. For example, a short story is developed by an author until it becomes a complete novel (Kristeva 1980, 90). 
iv. Demitefication.

Demitefication is a contradiction to the meaning of a text which appeared in earlier work. The author questioned the text before making a contradiction (Kristeva 1980, 103).

v. Haplology.

Haplology occurs when there are omissions upon the presence of texts into other texts. This process occurs during the selection and editing process for the purpose of making text adjustments in order to harmonize the work (Kristeva 1980, 25).

vi. Excerpt.

Excerpt happens when the text is the same as or perhaps similar to some essence, a quote, an episode or aspect of hipogram or the original text (Sardjono 1986, 63).

vii. Parallel.

A parallel occurs when there similarities or parallels between a text and other text(s) in terms of theme, idea or form of the text itself. Parallel Principles shows elements of parallelism and alignment of text within a text. However, the author should cite the source of the text so that it is not considered as plagiarism (Kristeva 1980, 91).

viii. Conversion.

Conversion happens when there is a distortion of the original text or hipogram or contradiction to the taken text. This resistance element is not the same as those in the demitefication principle. In fact, it is not so radical and does not undergo aggressive or drastic changes (Kristeva 1980, 107).

ix. Existence.

Existence occurs when elements created or organized in a work is distinctly different from its hypogram text. This process occurs when the author conducts a renewal of major works that form the basis of his/her writing (Kristeva 1980, 106-107).

$\mathrm{x}$. Defamiliarization.

Defamiliarization is an extraordinary element in a certain piece of work. It means the effort of an author to bring extraordinary elements by making changes to the text such as changes in terms of meaning or role played by a particular character in the piece of work (Kristeva 1980, 131).

Each of these principles does not have to appear separately in a certain work, which means that some of them could appear simultaneously. For example, when a particular text goes through a transformation process, it could also pass through the modification process, expansion or any other intertextual principles at the same time.

The use of the intertextual reading method is appropriate because this method has been used throughout the world since 1926 to facilitate readers to understand the difficult literature, and Tafsir Nur Al-Ihsan qualifies as difficult literature.

\section{Findings of the Study}

Sabab Nuzul Ayah (The Contexts and Occasions of The Revelation of The Quran) is one of many parts in Tafsir Nur Al-Ihsan. In debating it, the author uses 33 expressions that indicate that after the expression is the Sabab Nuzul Ayah ie; then down, down two verses in.., down, down the revelation, 
INTERNATIONAL JOURNAL OF ACADEMIC RESEARCH IN BUSINESS AND SOCIAL SCIENCES

Vol. 9, No. 2, Feb, 2019, E-ISSN: 2222-6990 C 2019 HRMARS

down this surah, down this verses, down this in..., down when..., down this surah and another surah, down this verses is because..., down Gabriel with..., Allah sends down... and down this burdah (Omar, 1970).

The author discusses the Sabab Nuzul Ayah in the first volume of 75 times and the most commonly used phrase is "down this sentence" which is 41 times. Twice in the first volume, eight times in the second volume, 11 times in the third volume and 20 times in the fourth volume. For example, when explaining the Sabab Nuzul Ayah of the 11th verse of Surah al-Hajj;

"down this sentence to the Arabian Badwi, after they claimed to be Muslims, they migrated with the Prophet. When they are healthy and have a lot of wealth, they remain in Islam. However, when they are ill or become poor, they do not believe in Allah SWT" (Omar, 1970).

In the second volume of Tafsir Nur Al-Ihsan, sabab nuzul ayah are discussed for 59 times, the third volume is 37 times and the fourth volume is 48 times making the third volume the least amount of sabab nuzul ayah is discussed. The expression that is rarely used by the author is "when down...", "and has gone down", "down by" and "down this verses is because..." in the first volume, "down Gabriel with...", "Allah sends down...", "down this burdah" in the second volume," down the verse when..." in the third volume and "down the two verses on...", "down the revelation", "down this surah and another surah" in the fourth volume (Omar, 1970).

Table 1 indicates the list of reference works of sabab nuzul ayah in Tafsir Nur al-Ihsan and intertextual principles using review content of Tafsir Nur al-Ihsan as a whole pertaining of Sabab Nuzul Ayah (The Contexts and Occasions of The Revelation of The Quran).

Table 1: The List of Reference Works of Sabab Nuzul Ayah in Tafsir Nur al-Ihsan and Intertextual Principles

\begin{tabular}{clcccccc}
\hline No. & \multicolumn{1}{c}{ Works } & Parallel & Excerpt & Haplology & Expansion & Existence & Total \\
\hline 1 & Tafsir al-Jalalyn & 89 & 11 & 3 & 27 & 2 & $\mathbf{1 3 2}$ \\
2 & Tafsir al-Jamal & 19 & 30 & 36 & 8 & 1 & $\mathbf{9 4}$ \\
3 & Tafsir al-Baydawi & 5 & 8 & 5 & 2 & 0 & $\mathbf{2 0}$ \\
4 & Tafsir al-Khazin & 9 & 16 & 19 & 4 & 1 & $\mathbf{4 9}$ \\
5 & Tafsir al-Qurtubi & 2 & 4 & 7 & 1 & 0 & $\mathbf{1 4}$ \\
6 & Tafsir al-Razi & 0 & 5 & 3 & 3 & 0 & $\mathbf{1 1}$ \\
7 & Tafsir al-Nasafi & 0 & 1 & 1 & 1 & 0 & $\mathbf{0 3}$ \\
\hline & & $\mathbf{1 2 4}$ & $\mathbf{7 5}$ & $\mathbf{7 4}$ & $\mathbf{4 6}$ & $\mathbf{0 4}$ & $\mathbf{3 2 3}$ \\
\hline
\end{tabular}

Table 1 reveals that the works which have been referred to by the author when discussing Sabab Nuzul Ayah in Tafsir Nur al-Ihsan are: Tafsir al-Jalalyn, Tafsir al-Jamal, Tafsir al-Baydawi, Tafsir alKhazin, Tafsir al-Qurtubi, Tafsir al-Razi, and Tafsir al-Nasafi. In addition, the principle of the intertextual principles used comprised of parallel, excerpt, haplology, expansion and existence principles. 
INTERNATIONAL JOURNAL OF ACADEMIC RESEARCH IN BUSINESS AND SOCIAL SCIENCES

Vol. 9, No. 2, Feb, 2019, E-ISSN: $2222-6990$ ๑ 2019 HRMARS

Table 2 shows the data that has been analyzed and the finding indicates that text from Tafsir alJalalyn has influenced Sabab Nuzul Ayah in Tafsir Nur al-Ihsan of 100 times (50\%), Tafsir al-Jamal 49 times (25\%), Tafsir al-Baydawi 13 times (6.5\%), Tafsir al-Khazin 25 times (12.5\%), Tafsir al-Qurtubi 07 times (3.5\%), Tafsir al-Razi 05 times (2.5\%) and Tafsir al-Nasafi 01 time (0.5\%). Therefore, this article proves that the work most widely referred to by Sheikh Muhammad Said relevant of Sabab Nuzul Ayah while writing Tafsir Nur al-Ihsan is Tafsir al-Jalalyn.

Table 2: List of Works Referred to on the Sabab Nuzul Ayah in Tafsir Nur al-Ihsan

\begin{tabular}{clcc}
\hline No. & \multicolumn{1}{c}{ Title of Works } & Frequency & Percentage \\
\hline 1 & Tafsir al-Jalalyn & 100 & $50 \%$ \\
2 & Tafsir al-Jamal & 49 & $25 \%$ \\
3 & Tafsir al-Baydawi & 13 & $6.5 \%$ \\
4 & Tafsir al-Khazin & 25 & $12.5 \%$ \\
5 & Tafsir al-Qurtubi & 07 & $3.5 \%$ \\
6 & Tafsir al-Razi & 05 & $2.5 \%$ \\
7 & Tafsir al-Nasafi & 01 & $0.5 \%$ \\
\hline & & $\mathbf{2 0 0}$ & $\mathbf{1 0 0 \%}$ \\
\hline
\end{tabular}

The finding of the study related to principles in intertextual used in Tafsir Nur al-Ihsan is shown in Table 3.

Table 3: Principles in Intertextual Used

\begin{tabular}{cccccccc}
\hline No. & Analysis & Parallel & Excerpt & Haplology & Expansion & Existence & Total \\
\hline 1 & Sabab Nuzul Ayah & 124 & 75 & 74 & 46 & 04 & $\mathbf{3 2 3}$ \\
\hline & Percentage & $38.3 \%$ & $23.2 \%$ & $22.9 \%$ & $14.2 \%$ & $1.2 \%$ & $100 \%$ \\
\hline
\end{tabular}

Table 3 reveals that there are five principles of intertextual approach used when the author narrates the Sabab Nuzul Ayah in Tafsir Nur al-Ihsan, which indicate 124 times of parallel (38.3\%), 75 times of excerpt (23.2\%), 74 times of Haplology (22.9\%), 46 times of Expansion (14.2\%), and four times of existence $(1.2 \%)$, which makes the principles most frequently used the author is parallel principle.

\section{Conclusion}

Tafsir Nur al-Ihsan is a work in the field of tafsir al-Quran written by Omar (1970). This work received widespread recognition not only in Malaysia but also in Indonesia, Egypt, and Thailand on par with another contemporary exegesis. What is interesting about this work is its simple style which is easily understood by society and also provides a variety of knowledge. In language style that's easy to the needs of all levels of society and appropriate use by modern civil society such as Malaysia.

In writing Tafsir Nur al-Ihsan , Omar (1970) referred to seven of famed works i.e. Tafsir al-Jalalyn, Tafsir al-Jamal, Tafsir al-Baydawi, Tafsir al-Khazin, Tafsir al-Qurtubi, Tafsir al-Razi and Tafsir al-Nasafi when discussing two hundred Sabab Nuzul Ayah (The Contexts and Occasions of The Revelation of The Quran) which are very interesting for society to learn. This study is able to reveal and identify sources of references for all the Sabab Nuzul Ayah. Therefore, this study finds that Omar (1970) not 
only used the unsupported statements but also his own opinions in the writing of Tafsir Nur al-Ihsan. The major finding of this study is that this study provides evidence that the main reference work of the author concerning the Sabab Nuzul Ayah in Tafsir Nur al-Ihsan was Tafsir al-Jalalyn based on the percentage of frequency used by Omar (1970) which indicates that Tafsir al-Jalalyn was the work which he referred to the most. While the Tafsir al-Jamal, Tafsir al-Baydawi, Tafsir al-Khazin, Tafsir alQurtubi, Tafsir al-Razi, and Tafsir al-Nasafi were its ancillary reference works. In addition, the principle of intertextual which was the most widely used was the parallel principle. Therefore, if there is any confusion and misunderstanding when using Tafsir Nur Al-Ihsan as a reference to understand the Qur'an, Muslim religious teachers, students and the public at large could refer to the references suggested by this study. It is significantly important to refer to the original sources referred to by Tafsir Nur Al-Ihsan in order to have a proper and true understanding of the holy Qur'an.

The text Tafsir Nur al-Ihsan does not include any citation and references. Therefore, the theoretical contribution of this study is that this study reveals the sources of references used in text and refine the text which contributes to improving the invaluable work. Thus, the contribution of this study is that this study is able to shed some lights on the shortcomings of Tafsir Nur al-Ihsan so that teachers and students using this book as a reference are made aware of it and able to find the truth by referring to the original sources.

In doing so, this study also makes a contextual contribution by revealing unfounded statements written in the text, thus able to shed some lights on any confusion and misunderstanding to the readers. This is a significant contribution because Tafsir Nur al-Ihsan has been used widely as a major textbook in Islamic religious institutions in Malaysia, Thailand, and Indonesia. It is hoped that the Muslim religious teachers and students who used this book to understand the Holy Qur'an would understand the true teachings of the Qur'an.

\section{References}

Abdul Rahman, A. R. (2010). Mengenali Tuan Haji Saaid Mufti Ulama Tersohor di Alam Melayu. Working Paper at Seminar Ulama Melayu. Shah Alam.

Abdul Razak, H. O. (2012). Riwayat Hidup Syeikh Muhammad Sa'id. Alor Setar.

Al-Baydawi, N. A. (1996). Tafsir Al-Baydawi. Beirut: Dar al-Fikr.

Al-Dhahabi, M.H. (1977). 'Ilm Al-Tafsir. Cairo: Dar al-Ma'arif.

Al-Jamal, S. (n.d.). Tafsir al-Jamal. Mesir: 'Isa al-Babi al-Halabi.

Al-Khazin, A.A. (1979). Tafsir Al-Khazin. Beirut: Dar al-Fikr.

Al-Nasafi, A. A. (1999). Tafsir Al-Nasafi, Madarik al-Tanzil Wa Haqaiq al-Ta'wil. Bayrut: Dar Ibn Kathir. Al-Qurtubi, A. A. (2003). Al-Jami' Al-Ahkam Al-Qur'an. Riyad: Dar 'Alim al-Kutub.

Al-Razi, M. D. (1981). Tafsir Mafatih I-Ghayb. Beirut: Dar al-Fikr.

Al-Suyuti \& Al-Mahalli. (1919). Tafsir Al-Jalalyn. Dimashq: Dar al-Ulum al-Insaniyyah.

Dostoyevsky, F. (1965). The Idiot: Transl. with an Introduction by David Magarshack. Penguin Books. Fadlan, M. O. (2009). Aplikasi Ilmu Takhrij Dalam Kitab Tafsir Melayu: Tinjauan Awal Terhadap Surah Al-Baqarah, Kitab Tafsir Nur Al-Ihsan Oleh Al-Shaykh Muhammad Sa'id Bin 'Umar. Working paper at Seminar Sehari Tokoh Tafsir Dunia Melayu. UNITEN. 
Ibn Khaldun, A. M. (2000). Muqaddimah Ibn Khaldun. Beirut: Dar Sadir.

Ibn Kathir, A. U. (1999). Tafsir Al-Qur'an Al-Azim. Al-Riyad: Dar Tayyibah.

Hawthorn, J. (2000). A Concise Glossary of Contemporary Literary Theory. London: Arnold.

Harari, J.V. (1979). Textual Strategies. New York: Cornell University Press.

Kristeva, J. (1980). Desire in Language: A Semiotic Approach to Literature and Art. Oxford: Basil Blackwell.

Mat Taib, M.I. (2003). Israiliyyat Dalam Tafsir: Kajian Terhadap Kitab Nur al-Ihsan, Karya Haji Muhammad Sa'id bin 'Omar. University of Malaya.

Omar, M.S. (1970). Tafsir Nur al-Ihsan. Fatani: Matba'ah Bin Halabi.

Sardjono, P. (1986). Kakawin Gajah Mada. Bandung: Penerbit Binacipta.

Schmitz, T. A. (2007). Modern Literary Theory and Ancient Texts: An Introduction. Victoria. Blackwell Publishing.

Wan Nasyrudin, W.A. (2008). Tafsir Tarjuman al-Mustafid: Kajian Intertekstual. PhDThesis, University of Malaya.

Zaim, M.N. (2010). Kajian Takhrij Hadith Dalam Tafsir Nur Al-Ihsan. Universiti Sains Malaysia. 